\section{Clinical and laboratory assessment of Mangalarga Marchador horses submitted to marcha exercise}

\author{
Avaliação clínica e laboratorial em equinos Mangalarga \\ Marchador submetidos ao exercício de marcha
}

José Dantas Ribeiro Filho'*, Rinaldo Batista Viana² ${ }^{2}$ Hélio Cordeiro Manso Filho ${ }^{3}$, Waleska de Melo Ferreira Dantas ${ }^{4}$, Micheline Ozana da Silva ${ }^{5}$, Pedro Ancelmo Nunes Ermita ${ }^{4}$, Samuel Rodrigues Alves ${ }^{6}$, Lorena Chaves Monteiro ${ }^{6}$ \& Caio Monteiro Costa ${ }^{6}$

'Veterinarian, DSc, Professor. Departamento de Veterinária - DVT, Centro de Ciências Biológicas e da Saúde - CCB, Universidade Federal de Viçosa - UFV, Viçosa, MG, Brasil

${ }^{2}$ Veterinarian, DSc, Professor. Instituto da Saúde e Produção Animal - ISPA, Universidade Federal Rural da Amazônia - UFRA, Belém, PA, Brasil

${ }^{3}$ Veterinarian, PhD, Professor. Departamento de Zootecnia- DZO, Núcleo de Pesquisa Equina - NPE, Universidade Federal Rural do Pernambuco, Recife, PE, Brasil

${ }^{4}$ Veterinarians, DSc. Departamento de Veterinária - DVT, Centro de Ciências Biológicas e da Saúde - CCB, Universidade Federal de Viçosa - UFV, Viçosa, MG, Brasil

${ }^{5}$ Physiotherapist, DSc. Departamento de Veterinária - DVT, Centro de Ciências Biológicas e da Saúde - CCB, Universidade Federal de Viçosa - UFV, Viçosa, MG, Brasil

${ }^{6}$ Veterinarians, MSc. Departamento de Veterinária - DVT, Centro de Ciências Biológicas e da Saúde - CCB, Universidade Federal de Viçosa - UFV, Viçosa, MG, Brasil

\begin{abstract}
This study aimed to verify the effects of marcha exercise on clinical, hematological, and biochemical variables in Mangalarga Marchador horses. Twelve Mangalarga Marchador horses were used, six females, and six males. Each animal was submitted to marcha exercise lasting 40 minutes on hard ground, a training regimen to which these animals were already conditioned. The animals were assessed before exercise(MO) and immediately after (M1). Physical examinations were carried out and blood samples were collected via jugular venipuncture to obtain blood, plasma, and serum for hematological and biochemical profiles. The marcha training caused changes in the values of all clinical and laboratory variables evaluated. The physical examinations revealed increases in cardiac and respiratory rates, as well as rectal temperatures. An increase was observed in erythrocyte, hemoglobin, hematocrit, and leukocyte values. The serum concentrations of electrolytes such as sodium, potassium, chloride, magnesium, and ionic calcium decreased. An increase in strong ion difference (SID) was observed, likely due to the decrease in chloride concentration causing a mild metabolic alkalosis. There was an increase in the plasma concentrations of lactate, glucose, creatine phosphokinase (CK), total protein, and fibrinogen. In conclusion, the marcha causes small changes in the clinical, hematological, and biochemical profiles of horses previously conditioned to this exercise.
\end{abstract}

Keywords: clinical biochemistry, equine, exercise physiology, hematology.

\section{Resumo}

Este estudo teve como objetivo verificar o efeito do exercício de marcha sobre variáveis clínicas, hematológicas e bioquímicas em equinos Mangalarga Marchador. Foram utilizados doze equinos da raça Mangalarga Marchador, seis fêmeas e seis machos. Cada animal foi submetido ao treinamento de marcha com duração de 40 minutos em solo duro. Esses animais já estavam condicionados ao treinamento proposto. Os animais foram avaliados antes do exercício (MO) e imediatamente após seu término (M1). Foram realizados exames físicos e colhidas amostras de sangue por venopunção jugular para obtenção de sangue total, soro e plasma para realização de análises hematológicas e bioquímicas em MO e M1. O treinamento de marcha gerou alteração nos valores de todas as variáveis clínicas elaboratoriais avaliadas. No exame físico foram observados aumentos nas frequências cardíacas e respiratória bem como na temperatura retal. Foi observado aumento nos valores de eritrócitos, hemoglobina, hematócrito e leucócitos. Eletrólitos como sódio, potássio, cloreto, magnésio e cálcio iônico apresentaram diminuição na sua concentração. Foi observado aumento na diferença de íons fortes (DIF) devido à diminuição da concentração de cloreto, sendo observado a presença de uma alcalose metabólica discreta. Observou-se aumento nas concentrações plasmáticas de lactato, glicose, CK, proteínas totais e fibrinogênio. Como conclusão, a marcha ocasiona pequenas mudanças no perfil clínico, hematológico e bioquímico em equinos previamente condicionados a este exercício.

Palavras-chave: bioquímica clínica, cavalos, fisiologia do exercício, hematologia.
How to cite: Ribeiro Filho, J. D., Viana, R. B. Manso Filho, H. C., Dantas, W. M. F., Silva, M. O., Ermita, P. A. N., Alves, S. R., Monteiro, L. C., \& Costa, C. M. (2018). Clinical and laboratory assessment of Mangalarga Marchador horses submitted to marcha exercise. Brazilian Journal of Veterinary Medicine, 40, e47418. doi: 10.29374/2527-2179.bjvm47418

Financial support: None.

Conflict of interests: No conflict of interests declared concerning the publication of this article.

Received: December 05, 2017. Accepted: June 27, 2018.

The study was carried out at Haras San Genaro, São Geraldo, MG, Brazil, and in the Laboratório de Pesquisa em Medicina Interna Veterinária, Departamento de Veterinária-DVT, Universidade Federal de Viçosa - UFV, Viçosa, MG, Brazil.

\section{*Correspondence}

José Dantas Ribeiro Filho

Departamento de Veterinária - DVT, Centro de Ciências Biológicas e da Saúde - CCB, Universidade Federal de Viçosa - UFV Av. PH Rolfs, s/n, Centro

CEP 36570-000 - Viçosa (MG), Brasil

E-mail: dantas@ufv.br 


\section{Introduction}

Physical training is a stressful condition that can cause important alterations to athlete homeostasis and can lead to injuries in different tissues, especially the musculoskeletal system. This leads to a decrease in athletic performance, duration of activity, and, consequently, financial losses for investors (Ferraz et al., 2007).

Because it is an exercise involving submaximal intensity and long duration, marcha training can induce the onset of dehydration as well as hydroelectrolytic and acid-base imbalances. These conditions occur mainly due to intense perspiration by the animals during physical activity (Balarin et al., 2005; Paludo et al., 2002).

The evaluation of physiological and biochemical parameters based on a controlled training schedule, even during physical activity, allows for more accurate evaluation of the changes promoted in the body with regard to the conditioning of the animals and the athletic capacity of each breed, in varied sporting activities (Silva et al., 2015). This evaluation has facilitated the preparation of training programs to be more technical, which will lead to improvements in the performance of competition horses.

Experimental studies on jumping, running, and endurance horses have been carried out to obtain information on the impact of exercise on the homeostasis of these animals. A large population of Mangalarga Marchador horses exists, and this breed is widely used in marcha national competition. Therefore, studies on the changes that occur during marcha exercise are of great importance for the improvement of athletic performance and the prevention of possible imbalances. We hypothesized that horses in marcha exercise have significant changes in the homeostasis. Consequently, this study aimed to evaluate the effects of marcha training on clinical, hematological, and biochemical variables of the Mangalarga Marchador horses.

\section{Material and methods}

The experiment was carried out on a property in the municipality of Muriaé - Minas Gerais (Latitude:-21.1306 and Longitude:-42.3664). Twelve Mangalarga Marchador horses (six non-castrated males and six non-pregnant females) aged between 3 and 11 years old and with good body scores condition (Speirs, 1997) were used. The average humidity and ambient temperature on the two days of data collection were $71 \%$ and $88 \%$ and $15.5^{\circ} \mathrm{C}$ and $21.5^{\circ} \mathrm{C}$, respectively. All experimental procedures were approved by the Ethics Committee in the use of animals of the Federal University of Viçosa (CEUA 04/2012).

Each animal was submitted to marcha training for 40 minutes on hard soil, with a 10-minute warm-up. These animals were already conditioned to this training and were maintained in a semi-intensive management system. Feeding consisted of diverse pastures of grasses, chopped elephant grass (Pennisetum purpureum) offered in the trough, Tifton hay (Cynodon sp.), and concentrate (Ration Soma Equinos 12, Soma Alimentos). Water and mineral supplements (Gusbiphos Centauro 80\%, Guabi Nutrition and Animal Health S.A.) were provided ad libitum. Clinical evaluations and collections for subsequent laboratory analysis were performed immediately before (MO) and after exercise (M1).

The clinical evaluation consisted of heart rate, respiratory rate, and rectal temperature measurements.

Venous blood samples were obtained by puncture of the jugular by means of a vacuum system. Multiple harvests were collected in silicone tubes containing EDTA-K2 anticoagulant to perform automated hemogram tests (HumaCaunt Plus, Human); in tubes containing EDTA-K2 and sodium fluoride to obtain plasma for glucose, lactate, total plasma protein, and fibrinogen analyses; and tubes without anticoagulant to obtain serum for analysis of sodium, potassium, chloride, magnesium, creatine phosphokinase (CK), and ionized calcium levels. Hematocrit was determined using the microhematocrit technique (Centrifuge 2410 - FANEM). Plasma protein and fibrinogen concentrations were determined by refractometry (Refractometer RTP2 - ATC), with the latter being determined after heat precipitation, as described by Thrall et al. (2015). 
The concentrations of sodium and potassium were determined using flame photometry (Photometry B462, Micronal). Ionized calcium was quantified using the automatic ion-selective technique(AVL, Roche). The other biochemical analyses were performed using an automated device (HumaStar300, Human) with commercial kits, according to the manufacturer's recommendations.

The strong ion difference (SID) was determined based on the following equation, suggested by Constable (1999):

$$
S I D=\left(\mathrm{Na}^{+}+\mathrm{K}^{+}\right)-\left(\mathrm{Cl}^{-}\right)
$$

Data were expressed as mean \pm standard deviation. The comparison of the means, among the times studied, was performed using a paired sample Student's $t$-test. Statistical significance was assumed at $P<0.05$ ( $\alpha=5 \%$ ). The statistical package SAEG 9.0 (Universidade Federal de Viçosa, 2007) was used.

\section{Results}

At the end of the exercises, all animals showed physical exhaustion, intense sweating, and a significant increase $(P<0.05)$ in heart rates, respiratory rates, and rectal temperature (Table 1$)$. Similar behavior was observed in the blood count variables, which presented significant elevation $(\mathrm{P}<0.05)$ in their values (Table 2). At the end of the exercise (M1) the serum levels of sodium, potassium, chloride, magnesium, and ionic calcium (Table 3$)$ presented a decrease $(P<0.05)$. There was an increase $(P<0.05)$ in plasma concentrations of lactate, glucose, CK, total plasma protein, and fibrinogen, as well as SID (Table 3).

Table 1. Mean and standard deviations of the heart rate (HR - bpm), respiratory rate (RR - mpm) and rectal temperature $\left(\mathrm{RT}-{ }^{\circ} \mathrm{C}\right.$ ) of Mangalarga Marchador Horses before (MO) and after (M1) marcha exercise, followed by their respective reference values (RV).

\begin{tabular}{cccc}
\hline VARIABLE & M0 & M1 & RV \\
\hline HR & $43.5 \pm 6.1^{\mathrm{a}}$ & $83.5 \pm 18.5^{\mathrm{b}}$ & $(28-40)$ \\
RR & $24.8 \pm 10.1^{\mathrm{a}}$ & $56.3 \pm 27.7^{\mathrm{b}}$ & $(10-14)$ \\
RT & $37.9 \pm 0.3^{\mathrm{a}}$ & $39.8 \pm 0.9^{\mathrm{b}}$ & $(37.5-38.0)$ \\
\hline
\end{tabular}

Different letters in the same line differ significantly $(P<0.05)$ between the values of their respective variables. RV = reference values (Speirs, 1997).

Table 2. Mean and standard deviations of erythrocytes $\left(\mathrm{mm}^{3}\right)$, hematocrit $(\%)$, hemoglobin $\left(\mathrm{g} \mathrm{dL}^{-1}\right)$, platelets $\left(10^{3} \mu \mathrm{L}^{-1}\right)$ and leukocytes $\left(\mathrm{mm}^{3}\right)$ of Mangalarga Marchador Horses before (MO) and after (M1) marcha exercise, followed by their respective reference values (RV).

\begin{tabular}{cccc}
\hline VARIABLE & M0 & M1 & RV \\
\hline Erytrocytes & $9.64 \pm 1.1^{\mathrm{a}}$ & $11.00 \pm 1.1^{\mathrm{b}}$ & $6.8-12.9$ \\
Hematócrit & $41.4 \pm 3.7^{\mathrm{a}}$ & $46.2 \pm 3.7^{\mathrm{b}}$ & $32-53$ \\
Hemoglobin & $14.0 \pm 1.3^{\mathrm{a}}$ & $15.0 \pm 1.2^{\mathrm{b}}$ & $11.0-19.0$ \\
Platelets & $108 \pm 38.6^{\mathrm{a}}$ & $123 \pm 37.3^{\mathrm{b}}$ & $100-350$ \\
Leukocytes & $10,360 \pm 1792.9^{\mathrm{a}}$ & $11,840 \pm 2074.6^{\mathrm{b}}$ & $5,400-14,300$ \\
\hline
\end{tabular}

Different letters in the same line differ significantly $(\mathrm{P}<0.05)$ between the values of their respective variables. $\mathrm{RV}=$ reference values (Weiss \& Wardrop, 2010). 
Table 3. Mean and standard deviations of sodium $\left(m E q L^{-1}\right)$, potassium $\left(m E q L^{-1}\right)$, chloride $\left(m E q L^{-1}\right)$, magnesium (mg dL $\left.{ }^{-1}\right)$, ionized calcium $\left(\mathrm{mmol} \mathrm{L}^{-1}\right), \operatorname{SID}\left(\mathrm{mmol} \mathrm{L}^{-1}\right)$, lactate $\left(\mathrm{mg} \mathrm{dL}^{-1}\right)$, glucose $\left(\mathrm{mg} \mathrm{dL}^{-1}\right)$, creatine phosphokinase $\left(\mathrm{U} \mathrm{L}^{-1}\right)$, total plasma protein $\left(\mathrm{g} \mathrm{dL}^{-1}\right)$ and fibrinogen $\left(\mathrm{g} \mathrm{dL}^{-1}\right)$ before $(\mathrm{MO})$ and after (M1) marcha exercise, followed by their respective reference values (RV).

\begin{tabular}{crrr}
\hline VARIABLE & M0 & M1 & RV \\
\hline Sodium & $136.4 \pm 2.9^{\mathrm{a}}$ & $135.4 \pm 2.8^{\mathrm{b}}$ & $132-156$ \\
Potassium & $4.13 \pm 0.5^{\mathrm{a}}$ & $3.6 \pm 0.3^{\mathrm{b}}$ & $3.0-5.0$ \\
Chloride & $96.9 \pm 6.7^{\mathrm{a}}$ & $91.7 \pm 1.9^{\mathrm{b}}$ & $99-109$ \\
Magnesium & $2.2 \pm 0.3^{\mathrm{a}}$ & $2.1 \pm 0.1^{\mathrm{b}}$ & $2.2-2.8$ \\
Ionized calcium & $1.6 \pm 0.1^{\mathrm{a}}$ & $1.5 \pm 0.2^{\mathrm{b}}$ & $1.4-1.7$ \\
SID & $43.7 \pm 2.2^{\mathrm{a}}$ & $47.3 \pm 1.7^{\mathrm{b}}$ & $37-43$ \\
Lactate & $6.9 \pm 1.5^{\mathrm{a}}$ & $22.8 \pm 20.3^{\mathrm{b}}$ & $10-16$ \\
Glucose & $98.5 \pm 14.6^{\mathrm{a}}$ & $107.1 \pm 13.4^{\mathrm{b}}$ & $75-115$ \\
CK & $328.3 \pm 93.0^{\mathrm{a}}$ & $402.5 \pm 122.1^{\mathrm{b}}$ & $145-380$ \\
TPP & $6.2 \pm 0.5^{\mathrm{a}}$ & $6.4 \pm 0.5^{\mathrm{b}}$ & $6.0-7.7$ \\
Fibrinogen & $0.3 \pm 0.2^{\mathrm{a}}$ & $0.4 \pm 0.2^{\mathrm{b}}$ & $0.2-0.4$
\end{tabular}

Different letters in the same line differ significantly $(P<0.05)$ between the values of their respective variables. SID $=$ Stron ion difference; $\mathrm{CK}=$ Creatine phosphokinase; TPP = total plasma protein; RV total plasma protein = reference values (Kaneko et al., 2008).

\section{Discussion}

The observed changes in heart rate are likely owing to sympathetic neural activity, which, according to Teixeira-Neto et al. (2004) and Ferraz et al. (2007), is the major factor responsible for the changes in physiological variables seen during exercise. The same authors observed that in purebred Arabian horses, the heart rate increased according to the intensity of the exercise. Merino et al. (1997), Perez et al. (1997), and Silva et al. (2005) obtained results similar to those of the present study when evaluating the cardiac and respiratory frequencies of horses, before and immediately after the end of the exercise. Paludo et al. (2002) suggested that an increase in respiratory rate is one of the first lines of physiological defense when the body is subjected to thermal stress or physical activity. In addition, the release of catecholamines during exercise stimulates bronchodilation, increasing respiratory rates, increasing alveolar ventilation (which favors heat dissipation), and the elimination of excess $\mathrm{CO}_{2}$ produced through muscle catabolism (Merino et al., 1997).

The average increase of $1.9^{\circ} \mathrm{C}$ in the rectal temperature of the animals was likely due to the production of heat resulting from an increase in cellular metabolism for energy production. These findings corroborate those obtained by McCutcheon \& Geor (2000), who observed a mean increase of $2.5^{\circ} \mathrm{C}$ in the rectal temperature of horses after exercise; and Merino et al. (1997) also observed an average increase of $2.0^{\circ} \mathrm{C}$ in rectal temperature when studying Chilean traction horses. Rectal temperature increases considerably in the horse during work of increasing intensity and duration (Poole \& Erickson, 2015), and adjusting it makes it possible to evaluate the thermoregulatory capacity of these animals when subjected to thermal stress, allowing inferences to be made on the dissipation of the excess heat produced (Paludo et al., 2002). In extended tests, such as endurance, it is common to have intervals during exercise where the animal is cooled and watered, which decreases the rectal temperature and improves control of other physiological functions (Brandi et al., 2009). Measurements in the present study were performed prior to any intervention, such as bathing or watering, which explains the rectal temperature values outside the reference range.

The observed increase in hemoglobin concentration, in the number of red blood cells and in hematocrit are associated with two fundamental conditions that are induced by exercise. The first one is dehydration due to the intense sweating that occurs during physical activity, resulting in reduced volemia with a relative increase in cellularity (Teixeira-Neto et al., 2004; 
Ferraz et al., 2009). The second associated condition is the release of adrenaline, triggered by arousal during exercise. This hormone acts on the smooth muscle of the spleen, stimulating its contraction and leading to the release of the red blood cells stored in this organ (Hyyppä et al., 1996). Adrenaline also stimulates leukocyte migration from the marginal pool, increasing the number of white blood cells in the circulating pool, which explains the increase in total leukocyte count (Thrall et al., 2015). The small increase in the number of platelets may be associated with the same physiological mechanisms that induced changes in white blood cells and erythrocytes. However, although the increase was significant $(P<0.05)$, it is not clinically relevant because, as with the other parameters, the values remained within the reference range.

The decrease observed in serum sodium, potassium, chloride, calcium, and magnesium concentrations is a result of the loss of electrolytes during intense sweating. According to Fernandes \& Larsson (2000) and Ribeiro et al. (2004), these are the main electrolytes found in horses' sweat, supporting the results of the present study. As can be observed in Table 3, the decrease in serum electrolyte concentration was discrete; however, it should be emphasized that, depending on the intensity and duration of the exercise, environmental conditions, degree of hydration, and physical conditioning, these losses can become more pronounced, leading to significant hydroelectrolytic and acidic-base imbalances (McCutcheon \& Geor, 1998; Fernandes \& Larsson, 2000; Martins et al., 2017).

The sweat of horses has high chloride and low sodium concentrations. The amount of chloride in sweat is twice that of its concentration in plasma and, therefore, prolonged sweating may result in hypochloremia (Frape, 2004). Excessive chloride loss results in an increase in the absorption of bicarbonate by the kidneys to maintain electroneutrality, which in turn may lead to hypochloremic metabolic alkalosis (DeMorais \& Biondo, 2012). Based on the findings of the present study, it can be inferred that the physical activity caused the onset of the acid-base disorder mentioned, because the decrease in chloride concentration was sufficient to alter the SID which, according to the same authors, in the hypochloremic metabolic alkalosis, values above the maximum reference limits. Results similar to the present assay were obtained by Martins et al. (2017).

The concentration of potassium in sweat is 8 to 20 times greater than its concentration in plasma and, as sweating occurs more intensely during physical activity, a decrease in the concentration of this electrolyte after exercise is not surprising (Cohen et al., 1993; Flaminio \& Rush, 1998). The reduction in potassium concentration may also be potentiated by elevated glycemia resulting from increased metabolism, leading to pancreatic release of insulin, which stimulates the influx of $\mathrm{K}^{+}$into cells; it may also be potentiated by an increase in the concentration of aldosterone during physical activity, which increases the absorption of sodium in the renal tubules with a consequent increase in potassium excretion (Stephenson, 2014). Hypochloremic metabolic alkalosis also has an influence on the reduction in $\mathrm{K}^{+}$concentration through $\mathrm{K}^{+}$influx, as cells attempt to maintain electroneutrality between the intra- and extracellular compartments (Flaminio \& Rush, 1998).

The concentrations of magnesium, potassium, and chloride in sweat are higher than in plasma. Thus, intense sweating may lead to the reduction of serum $\mathrm{Mg}^{2+}$, as found by Sampieri et al. (2006). As can be observed in Table 3, the animals in the present study presented mild hypomagnesaemia but did not develop any clinical signs.

The reduction of ionized calcium observed in the present study is an important result, which has also been reported by White (1998), Aguilera-Tejero et al. (2001), Santos et al. (2001), and Ribeiro et al. (2004) who observed muscle tremors in some animals and associated this signal with a decrease in $\mathrm{Ca}^{2+}$ concentration. Flaminio \& Rush (1998) further mention that the decrease in ionized calcium can result from metabolic alkalosis produced through exercise. Despite the significant reduction in the values of ionized calcium, all the equines presented concentrations within the reference range for the species.

According to Balarin et al. (2005) and Brandi et al. (2009), the variation in glycemia is strongly related to the type of training, intensity, duration, and stress of the physical effort. According to the same authors, these factors will intensify gluconeogenic activity, mainly via the lipolytic pathway, in addition to the effect of hepatic glycogenolysis. Evaluating horses submitted to marcha exercise, Martins et al. (2017) also observed increased glycemia, as seen in the present study, and Teixeira \& Padua (2002) detected an increase in circulating glucose levels in Thoroughbreds immediately 
after a race. The effect of the type of physical activity on glycemia is confirmed by Fernandes \& Larsson (2000), who observed a reduction in glucose concentration when studying the effects of endurance tests (maximum intensity) on horses.

As mentioned, physical activity increases energy demand in skeletal muscles. In strenuous exercises, such as marcha training, there may be insufficient oxygen supply to the muscles, compromising energy production by the oxidation of glucose in the aerobic glycolysis pathway. Consequently, the skeletal muscles intensify anaerobic energy production and can increase lactate production in a way that the elimination/consumption pathways (cellular oxidation and consumption by the Cori cycle) are unable to, under the same conditions (Watanabe et al., 2006; Moreira et al., 2015). In the present study, we found that the increase in lactate concentrations may be responsible for the appearance of acid-based disorders such as metabolic acidosis (White, 1998; Gomide et al., 2006), although such disorders were not observed in this work. It should be noted that lactate variation during physical activity is inversely related to the animal's conditioning, as demonstrated by Barton et al. (2003) and Fielding et al. (2009).

CK is an enzyme found in many cell types, but its specificity is related to skeletal musculature (Carlson, 1993; Stockham, 1995; Hoffmann \& Solter, 2008; Valberg, 2008). In this way, an increase in the levels of $\mathrm{CK}$ would be a physiological consequence of the type of exercise performed. Based on the CK indexes found in the animals in the present study, it can be suggested that exercise caused slight injury to the musculature. An increase in CK levels was also reported by Merino et al. (1997) and Perez et al. (1997) when evaluating traction horses during field work and horses that competed in rodeo tests, respectively.

Despite an increase in fibrinogen concentration (Table3), values remained within the reference limits (Radostits et al., 2007; Kaneko et al., 2008) and were without clinical significance.

\section{Conclusion}

The training program for the proposed marcha tests can generate changes in clinical, hematological, and biochemical profiles. In this way, horses submitted to more intense exercise programs may present greater alterations in the hydroelectrolytic and acid-base balance. Further studies evaluating other parameters in horses submitted to marcha are necessary for a complete verification of the changes caused by this type of exercise.

\section{References}

Aguilera-Tejero, E., Estepa, J. C., López, I., Bas, S., Garfia, B., \& Rodríguez, M. (2001). Plasma ionized calcium and parathyroid hormone concentrations in horses after endurance rides. Journal of the American Veterinary Medical Association, 219(4), 488-490. http://dx.doi.org/10.2460/javma.2001.219.488. PMid:11518176.

Balarin, M. R. S., Lopes, R. S., Kohayagawa, A., Laposy, C. B., \& Fonteque, J. H. (2005). Assessement of glycaemia and serum activities of aspartate aminotransferase, creatinekinase, gamma glutamyltransferase and lactate dehydrogenase in thoroughbred horses submitted to exercise of different intensities. Semina: Ciências Agrárias, 26(2), 211-218. http://dx. doi.org/10.5433/1679-0359.2005v26n2p211.

Barton, M. H., Williamson, L., Jacks, S., \& Norton, N. (2003). Body weight, hematologic findings, and serum and plasma biochemical findings of horses competing in a 48-, 83-, or 159-km endurance ride under similar terrain and weather conditions. American Journal of Veterinary Research, 64(6), 746-753. http://dx.doi.org/10.2460/ ajvr.2003.64.746. PMid:12828261.

Brandi, R. A., Furtado, C. E., Martins, E. N., Freitas, E. V. V., Lacerda Neto, J. C., Queiroz Neto, A., \& Ribeiro, L. B. (2009). Endurance race equines performance fed diets with oil levels. Revista Brasileira de Saúde e Produção Animal, 10, 311-321.

Carlson, G. P. (1993). Testes de química clínica. In B. P. Smith (Ed.), Tratado de medicina interna de grandes animais (1a ed., pp. 395-427). São Paulo: Manole.

Cohen, N. D., Roussel, A. J., Lumsden, J. H., Cohen, A. C., Grift, E., \& Lewis, C. (1993). Alterations of fluid and electrolyte balance in Thoroughbred racehorses following strenuous exercise during training. Canadian Journal of Veterinary Research, 57(1), 9-13. PMid:8431806.

Constable, P. D. (1999). Clinical assessment of acid-base status: strong ion difference theory. Veterinary Clinical of North America Food Animal Practice, 15(3), 447-471. http://dx.doi.org/10.1016/S0749-0720(15)30158-4. PMid:10573806.

DeMorais, H. A., \& Biondo, A. W. (2012). Disorders of chloride: hyperchloremia and hypochloremia. In S. P. Dibartolla (Ed.), Fluid, electrolyte and acid-base disorders in small animal practice (4th ed., pp. 80-91). St. Louis: Elsevier. 
Fernandes, W. R., \& Larsson, M. H. M. A. (2000). Alterations of seric glucose, sodium, potassium, urea and creatinine levels in equines submitted to endurance race of $30 \mathrm{~km}$ with controled speed. Ciência Rural,30(3), 393-398. http://dx.doi.org/10.1590/S0103-84782000000300003.

Ferraz, G. C., Escodro, P. B., \& Neto, A. Q. (2007). Fisiologia do exercício equino: ferramenta para o desempenho atlético de cavalos atletas. Brazilian Journal of Equine Medicine, 12, 6-8.

Ferraz, G. C., Teixeira-Neto, A. R., D'Angelis, F. H. F., Lacerda-Neto, J. C., \& Queiroz-Neto, A. (2009). Alterações hematológicas e cardíacas em cavalos Ârabes submetidos ao teste de esforço crescente em esteira rolante. Brazilian Journal of Veterinary Research and Animal Science, 46(6), 431-437. http://dx.doi.org/10.11606/ S1413-95962009000600001.

Fielding, C. L., Magdesian, K. G., Rhodes, D. M., Meier, C. A., \& Higgins, J. C. (2009). Clinical and biochemical abnormalities in endurance horses eliminated from competition for medical complications and requiring emergency medical treatment: 30 cases (2005-2006). Journal of Veterinary Emergency and Critical Care, 19(5), 473-478. http://dx.doi.org/10.1111/j.1476-4431.2009.00441.x. PMid:19821889.

Flaminio, M. J. B., \& Rush, B. R. (1998). Fluid and electrolyte balance in endurance horses. The Veterinary Clinics of North America: Equine Practice,14(1), 147-158. http://dx.doi.org/10.1016/S0749-0739(17)30217-1. PMid:9561693.

Frape, D. L. (2004). Equine nutrition and feeding (3rd ed.). Victoria: Blackwell Publishing. http://dx.doi. org/10.1002/9780470751053.

Gomide, L. M. W., Martins, C. B., Orozco, C. A. G., Sampaio, R. C. L., Belli, T., Baldissera, V., \& Lacerda Neto, J. C. (2006). Blood lactate concentrations of horses competing in the resistance phase of 3-day combined training event. Ciência Rural, 36, 509-513. http://dx.doi.org/10.1590/S0103-84782006000200022.

Hoffmann, W. E., \& Solter, P. F. (2008). Diagnostic enzymology of domestic animals. In J. J. Kaneko, J. W. Harvey \& M. L. Bruss (Eds.), Clinical biochemistry of domestic animals (6th ed., pp. 351-378). San Diego: Academic Press. http://dx.doi.org/10.1016/B978-0-12-370491-7.00012-X.

Hyyppä, S., Saastamoinen, M., \& Pösö, A. R. (1996). Restoration of water and electrolyte balance in horses after repeated exercise in hot and humid conditions. Equine Veterinary Journal, 28(S22), 108-112. http://dx.doi. org/10.1111/j.2042-3306.1996.tb05038.x. PMid:8894557.

Kaneko, J. R., Harvey, J. W., \& Bruss, M. L. (2008). Clinical biochemistry of domestic animals (6th ed.). San Diego: Academic Press.

Martins, L. P., Di Filippo, P. A., Meireles, M. A. D., Peçanha, R. M. S., Mello, L. M., Ribeiro, L. M. F., \& Viana, I. S. (2017). Effect of marcha exercise on serum electrolytes and acid-base balance in Mangalarga Marchador horses. Journal of Equine Veterinary Science, 49, 108-112. http://dx.doi.org/10.1016/j.jevs.2016.10.018.

McCutcheon, L. J., \& Geor, R. J. (1998). Sweating: fluid and ion losses and replacement. The Veterinary Clinics of North America: Equine Practice, 14(1), 75-95. http://dx.doi.org/10.1016/S0749-0739(17)30213-4. PMid:9561689.

McCutcheon, L. J., \& Geor, R. J. (2000). Influence of training on sweating responses during submaximal exercise in horses. Journal of Applied Physiology, 89(6), 2463-2471. http://dx.doi.org/10.1152/jappl.2000.89.6.2463. PMid:11090603.

Merino, M. V., Valenzuela, A. S., Cabezas, I., Garcia, M., Ávila, C. G., \& Perez, R. (1997). Physiological and biochemical response of the draught horse to plowing in rice fields. Archivos de Medicina Veterinaria, 29, 235-241.

Moreira, D. O., Leme, F. O. P., Marques, M. M., Leão, N. F., Viana, W. S., Faleiros, R. R., \& Alves, G. E. S. (2015). Proteins, lactate, glucose, calcium, phosphorus, urea and Creatinine blood levels in military cavalry horses before and after urban patrolling. Ciência Animal Brasileira, 16(1), 73-80. http://dx.doi.org/10.1590/1089-6891v16i115233.

Paludo, G. R., McManus, C., Melo, R. Q., Cardoso, A. G., Mello, F. P. S., Moreira, M., \& Fuck, B. H. (2002). Effect of heat stress and exercise on physiological parameters of horses of the brazilian army. Revista Brasileira de Zootecnia, 31(3), 1130-1142. http://dx.doi.org/10.1590/S1516-35982002000500009.

Perez, R., García, M., Cabezas, I., Guzmán, R., Merino, V., Valenzuela, S., \& Gonzalez, C. (1997). Physical activity, cardiovascular and biochemical changes of Chilean purebred horses to rodeo competitions. Archivos de Medicina Veterinaria, 29, 221-234.

Poole, D. C., \& Erickson, H. H. (2015). Exercise physiology of terrestrial animal. In W. O. Reece, H. H. Erickson, J. P. Goff \& E. E. Uemura (Eds.), Dukes' physiology of domestic animal (13th ed., pp. 443-463). Cornell: Wiley-Blackwell.

Radostits, O. M., Gay, C. C., Hinchcliff, K. W., \& Constable, P. D. (2007). Veterinary medicine: a textbook of the diseases of cattle, sheep, goats, pigs and horse (10th ed.). Edinburg: Saunders,.

Ribeiro, C. R., Martins, E. A. N., Ribas, J. A. S., \& Germinaro, A. (2004). Serum biochemistry evaluation in horses and mules submitted to endurance ride of $76 \mathrm{~km}$ in the Pantanal region, state of Mato Grosso, Brazil. Ciência Rural, 34, 1081-1086. http://dx.doi.org/10.1590/S0103-84782004000400018.

Sampieri, F., Schott 2nd, H. C., Hinchcliff, K. W., Geor, R. J., \& Jose-Cunilleras, E. (2006). Effects of oral electrolyte supplementation on endurance horses competing in $80 \mathrm{~km}$ rides. Equine Veterinary Journal, 38(S36), $19-26$. http://dx.doi.org/10.1111/j.2042-3306.2006.tb05507.x. PMid:17402386.

Santos, S. A., Silva, R. A. M. S., Azevedo, J. R. M., Mello, M. A. R., Soares, A. C., Sibuya, C. Y., \& Anaruma, C. A. (2001). Serum electrolyte and total protein alterations in Pantaneiro horse during long distance exercise. Arquivo Brasileiro de Medicina Veterinária eZootecnia, 53(3), 351-357. http://dx.doi.org/10.1590/S0102-09352001000300013.

Silva, L. D., Santos, S. A., Silva, R. A. S., Mcmanus, C., \& Petzold, H. (2005). Physiological adaptations of the pantaneiro horse to stress related to daily work with cattle in the pantanal, Brazil. Archivos de Zootecnia, 54, 509-513. 
Silva, M. C., Berkman, C., Badial, P. R., Sarmento, E. B., Oliveira, N. F., Raphael, U. B., Medeiros, J. M. Q., \& Teixeira, L. G. (2015). Physiological and biochemical findings in Mangalarga Marchador horses during official competition of marcha. Veterinary Science of the Tropic, 18, 52-57.

Speirs, V. C. (1997). Clinical examination of horses. Philadelphia: Saunders.

Stephenson, R. B. (2014). Cardiovascular physiology. In B. G. Klein (Ed.), Cunningham tratado de fisiologia veterinária (5a ed., pp. 158-262). Rio de Janeiro: Elsevier-Saunders.

Stockham, S. L. (1995). Interpretation of equine serum biochemical profile results. The Veterinary Clinics of North America: Equine Practice, 11(3), 391-414. http://dx.doi.org/10.1016/S0749-0739(17)30307-3. PMid:8925417.

Teixeira, P. P., \& Padua, J. T. (2002). Evaluation of cortisol, thyroxine, triiodothyronine and glucose levels as stress indicatives in thoroughbred racehorses, before and after the competition. Ciência Animal Brasileira, 3, 39-48.

Teixeira-Neto, A. R., Ferraz, G. C., Mataqueiro, M. I., Lacerda-Neto, J. C., \& Queiroz-Neto, A. (2004). Electrolyte reposition on physiologic variables of horses submitted to 30 and $60 \mathrm{~km}$ endurance rides. Ciência Rural, 34(5), 1505-1511. http://dx.doi.org/10.1590/S0103-84782004000500028.

Thrall, M. A., Weiser, G., Allison, R. B., \& Campbell, T. W. (2015). Hematologia e bioquímica clínica veterinária (2a ed.). São Paulo: Roca.

Universidade Federal de Viçosa - UFV. (2007). Sistema para Análises Estatísticas (SAEG), versão 9.1. Viçosa: Fundação Arthur Bernardes.

Valberg, S. J. (2008). Skeletal muscle function. In J. J. Kaneko, J. W. Harvey \& M. L. Bruss (Eds.), Clinical biochemistry of domestic animals (6th ed., pp. 458-484). San Diego: Academic Press. http://dx.doi.org/10.1016/ B978-0-12-370491-7.00015-5.

Watanabe, M. J., Thomassian, A., Teixeira Neto, F. J., Alves, A. L. G., Hussni, C. A., \& Nicoletti, J. L. M. (2006) Alterações do pH, da PO2 e da PCO2 arteriais e da concentração de lactato sangüíneo de cavalos da raça Árabe durante exercício em esteira de alta velocidade. Arquivo Brasileiro de Medicina Veterinária e Zootecnia, 58(3), 320-326. http://dx.doi.org/10.1590/S0102-09352006000300006.

Weiss, D. J., \& Wardrop, K. J. (2010). Schalm's veterinary hematology (6th ed.). Ames: WileyBlackwell.

White, S. L. (1998). Fluid, electrolyte, and acid-base balances in three-day, combined-training horses. The Veterinary Clinics of North America: Equine Practice, 14(1), 137-145. http://dx.doi.org/10.1016/S0749-0739(17)30216-X. PMid:9561692. 